सeromanom

Mansoura University

Faculty of Tourism and Hotels

\title{
Controlling Waste Makes a Difference AT THE FAST FOOD RESTAURANTS
}

Extract of Master Thesis

By

Ahmed Mahmoud Sobhy

Master Researcher

Faculty of Tourism and Hotels - Mansoura University

DR/ Mohamed Abd ElFattah Zohry

Ass. Prof of Hotel management-

Faculty of Tourism and Hotels -

Mansoura University
Dr/Sameh Gamal Saad

Ass. Prof of Hotel managementFaculty of Tourism and Hotels Helwan University

\section{Abstract}

Reducing food waste is a key sustainability challenge for the food service industry. The importance of waste line in all restaurants is classified as managerial and economical approaches. The research focused on controlling waste in a sample of Egyptian fast food restaurants. To fulfill this objective, a personal interview with a sample of multinational and local chains was used. The findings illustrated that the increase in waste is extremely located at the low volume restaurants. The customer profile is different and also the operation procedures.

KEY WORDS: Waste line, fast food restaurants, multinational and local chains, customer profile. 
- Controlling Waste Makes a Difference at the Fast Food Restaurants

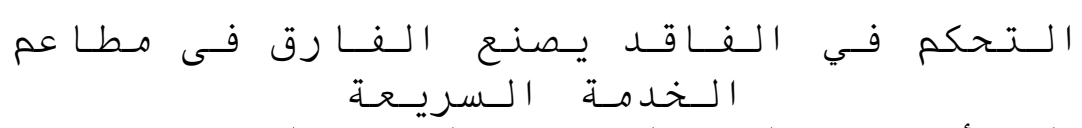

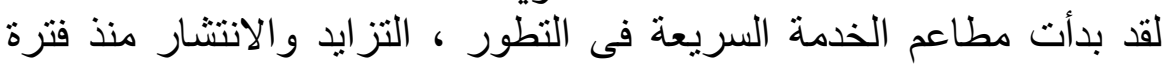

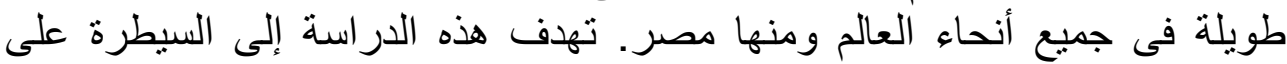

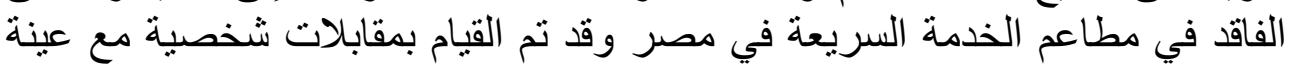

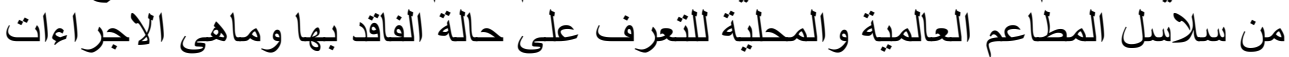

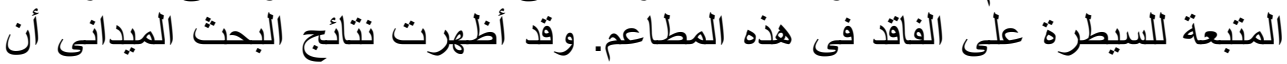

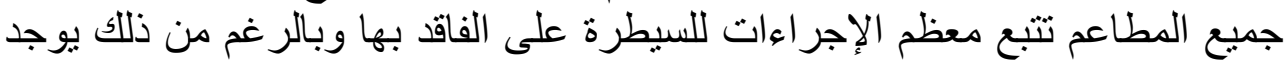

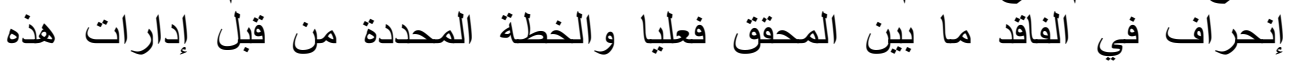

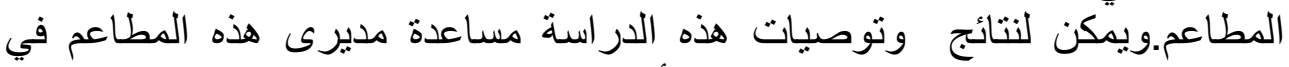

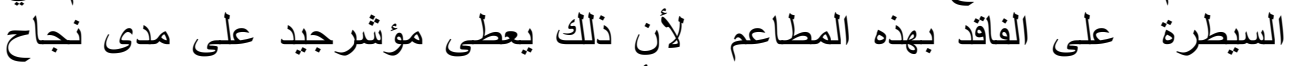

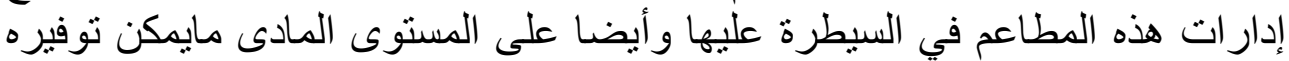

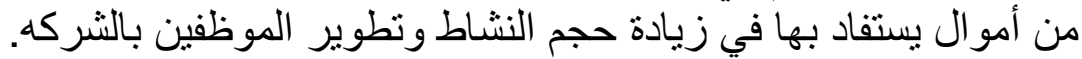

\section{Review of Literature}

\section{An overview of Fast Food Restaurants}

Fast food is the term given to foods that are prepared and served very quickly. They were first popularized in the 1950s, in the United States (Talwar, 2003; Ejike and Obeagu, 2018). FF restaurants are also known as quick service restaurants, where customers order items and, in most cases, pay before eating (Wang et al., 2016).

\section{Restaurant waste management}

Food waste management in the food service industry is a complex phenomenon and spans a wide range of factors and activities (Rios et al., 2018). Waste is a key issue for restaurants. Controlling waste needs to observe and maintain the following.

1-Healthy working environment.

2-Effective training programs.

3-Controlling the food cycle according to standards and procedures.

4-Tracking and analyzing the waste in every shift.

5-The waste sheet and waste buckets must be visible and easy 
مجلة كلية السياحة والفنادق - عدد ^- ديسمبر .r.r.

accessible.

6 Creating a responsible team for waste line.

7-Evaluting the waste amount at the management weekly meeting.

8-Managers effectiveness.

9-The management team must be aware of P\&L sheet.

10-Excellency of hospitality.

11-The front line staff must be aware of the components of any item.

12-Staff selection.

13- Efficient home delivery service.

14-High effective communication between restaurants.

15- Connecting waste with KPIs.

16-Making a menu engineering periodically.

17-The menu board and menu flyers must explain the ingredients of each item completely.

18-Recipes and quality guide charts.

19-Layout and design.

20-The construction issues.

\section{1- Healthy working environment.}

According to other published papers (Addis and Sala, 2007; Wall and Berry, 2007) restaurant environment and its visual appearance affect the level of acceptability of prices, overall satisfaction and loyalty.

\section{2-Effective training programs.}

The importance of training employees to meet company standards, industry standards, regulatory standards, and consumer expectations cannot be overemphasized; this is one of the key elements to help a company survive and be competitive (Hui et al., 2003).

\section{3-Controlling the food cycle according to standards and procedures.}




\section{A-Ordering:}

According to Vrat (2014), the ability to represent an inventory problem by a model allows to rationally decide how much to buy and when to buy.

\section{B-Receiving:}

The most common strategy applied at the receiving point for minimizing food waste is to check deliveries to ensure food is free of contaminants, meets specifications, does not expire and does not damage the packaging ( Pirani and Arafat, 2014 ;Charlebois et al., 2015).

\section{C-Storing:}

Adequate storage space is an important part of food waste reduction, enabling food service staff to properly store food as well as enabling food to be stored in a way that enables convenient access to food items (Engström and CarlssonKanyama, 2004).

\section{D- Preparation:}

In the preparation and production phases, food waste is minimized by avoiding over-cutting of ingredients especially bulk meats and whole vegetables (Pirani and Arafat, 2014; Creedon et al., 2010; LeanPath, 2016).

\section{E-Cooking:}

Regular equipment cleaning and maintenance increases compressor life, while preventing food spoilage that could otherwise be caused by equipment breakdowns (Creedon et al., 2010).

\section{F-Holding:}

Maintenance of a good temperature during food keeping leads to the prevention of food waste as it protects food health and prevents food spoilage (Betz et al., 2015; Creedon et al., 2010; Engström and Carlsson-Kanyama, 2004).

\section{G-Serving:}




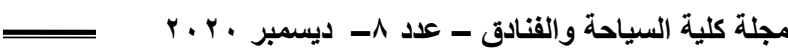

Service quality is a critical component of customer perceptions about the service (Hisam et al., 2016).

4-Tracking and analyzing the waste in every shift.

Based on the supervisors and workers of KFC \& Pizza Hut answers, the implementation of waste management will be completed when the communication about waste management is delivered as good as possible, they have same method to communicate from managers to workers using a daily briefing in the morning and in the work shift turnover (Alfagi et al., 2015).

\section{5- The waste sheet and waste buckets must be visible and easy accessible.}

Nonetheless, lack of awareness on food waste is one of the reasons for the slow progress in reducing food waste (Darqui et al., 2016).

\section{6- Creating a responsible team for waste line.}

They need to share responsibility and work together to reduce food waste (Göbel et al., 2015).

7-Evaluting the waste amount at the management weekly meeting.

Research (Goonan et al., 2014, Heikkila et al., 2016) shows that communication, which is a part of the management subsystem; influence the production of food waste.

\section{8-Managers effectiveness.}

An efficient management program has a major impact on the reduction and prevention of food waste according to Heikkila et al. (2016).

\section{9-The management team must be aware of $P \& L$ sheet.}

The worldwide restaurant industry faces major challenges today, one of which is to find an appropriate balance between serving customers' diverse needs while pricing its menu items to 
achieve adequate profitability levels (Raab et al ., 2010).

\section{0-Excellency of hospitality.}

Growing competition in the restaurant industry and the increasing importance of customer patronage affect the need to provide better service and satisfy consumers (Ladhari et al., 2008).

\section{1-The front line staff must be aware of the components of any item.}

Researchers are increasingly paying attention to the study of employees. Responsible for front line interaction with customers (Susskind et al., 2003).

\section{2-Staff selection.}

If the employees are incompetent, much of the management's time would be spent in close, direct supervision and checking of the employees' work (Hui et al., 2003).

\section{3- Efficient home delivery service.}

It will improve overall service satisfaction and loyalty when customers receive good service behavior (J. Gountas \& S. Gountas, 2007).

\section{4-High effective communication between}

\section{restaurants.}

Communication, a way to transmit and disseminate information within an organization, is an essential prerequisite for business success (Răducan \& Răducan, 2014).

\section{5-Connecting waste with KPIs.}

Many studies emphasize the importance of first-line employees, believing that they are a significant determinant of the quality of business service and operational success (Wen et al., 2013).

\section{6- Making a menu engineering periodically.}




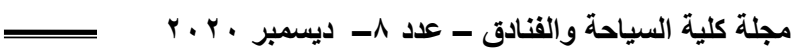

Retaining customers has become an important goal for organizations (Beatson et al., 2008).

\section{7- The menu board and menu flyers must explain the ingredients of each item completely.}

Precise ordering and food ordering tend to lead to the avoidance of food waste during service (Creedon et al., 2010), therefore the consumer should know the portion of and item on the menu board and the menu flyer.

\section{8-Recipes and quality guide charts.}

Quality is a competitive advantage. A business that can delight customers by improving and controlling quality can dominate its competitors (Montgomery, 2009). There must be product guide charts at the work stations.

\section{9-Layout and design.}

Processing equipment should have $(1 \mathrm{~m})$ of clear space around it to facilitate maintenance and cleaning. A minimum of $(0.5 \mathrm{~m})$ of clearance over each piece of equipment should be provided to permit effective cleaning (Marriot et al., 2018).

\section{0-The construction issues.}

Exhaust ventilation hood systems in food preparation and ware washing areas including components such as hoods, fans, guards, and ducting should be designed to prevent grease or condensation from draining or dripping onto food, equipment, utensils, linens, and single-service and single-use articles (Hui et al ., 2003).

\section{The impact of the Waste on People, Customer and Owner:}

Humans have always produced waste and disposed it in some way, so waste management is not a new issue. What has changed are the types and amounts of waste produced, the methods of disposal, and the human values and perceptions of what should be done with it (USEPA, 2009). 
In fact the increase in waste percentage affects negatively on people, customer and owner as follows:

\section{A-People:}

According to Kukanja (2013), individuals are primarily motivated by the attributes that meet their most important needs. Any increase in waste plan usually reflects a bad indicator for the people on the business as the operation team, commissary team and logistics team.

\section{B-Customer:}

Focusing on business 's short cuts may result in offering poor service to customers and even offering wasted food to them. In the restaurant business, satisfied customers will return and provide positive word of mouth to peers (Josiam et al., 2014).

\section{C-Owner:}

The owner wants to gain from the business, and any wasted food means wasted money to him. Companies spend huge money for creating loyalty of their customer but normally overlook the serious aspect of increasing the employee's motivation for achieving their economic and nonfinancial objectives (Shahzad, 2018).

\section{The Research Methodology Research Sample}

As per (Ghauri amd Gronhaug, 2005). Research methodology can be expressed as a system of roles and procedures. (Saunders et al., 2007). Stated that research methodology is a theory of how research should be undertaken, including the theoretical and philosophical assumptions upon which the research is based and implications of these for the methods or methods adopted.

In this study, a convenience sample of fast food restaurants was used. A number of thirty personal interviews forms were distributed at a sample of fast food restaurants, local and 
مجلة كلية السياحة والفنادق - عدد ^- ديسمبر ·r.r.

multinational restaurants in Egypt. It has been distributed at six chains, three multinational chains and three local chains. See table (1) the purpose of this form is to know how restaurants control waste. The personal interviews are completed from October 2018 -November 2019.

\begin{tabular}{|l|l|l|}
\hline \multicolumn{2}{|l|}{ Table 1: The selected investigated restaurants } \\
\hline Chain & Chain Sort & Restaurants Numbers \\
\hline KFC & Multinational & 211 Branches \\
\hline Hardees & Multinational & 75 Branches \\
\hline Burger King & Multinational & 23 Branches \\
\hline Prego & Local & 16 Branches \\
\hline Arabiata & Local & 18 Branches \\
\hline Batates \& Zalabya & Local & 65 Branches \\
\hline
\end{tabular}

The data is collected by the researcher.

The interview questions prepared for this study are based on a comprehensive literature review. The interview is divided into (41) questions. Interviews were carried out with area managers and operation managers of the investigated fast food restaurants. Interview questions were about the concept of controlling waste from their point of view as follows: What are the waste plans for the restaurants? What are the procedures to control waste at the restaurants? What are the berries to control waste effectively? Finally, they have been questioned, what is the role of upper management to support them to achieve their objectives?

\section{Results and Discussion}

As mentioned previously, the study concerned with a sample of fast food restaurants chains even multinational or local chains and what they are doing to control waste at these restaurants. The personal interview `s questions are extracted and highly based on the controlling waste points. 
- Controlling Waste Makes a Difference at the Fast Food Restaurants

\section{The waste plan and the actual waste at the} investigated restaurants.

The aim of this question is to know the amount of waste deviation if there is.

\begin{tabular}{|l|l|l|l|l|}
\hline $\begin{array}{l}\text { Table 2: The waste plan and actual waste at different } \\
\text { restaurants }\end{array}$ \\
\hline Restaurant & Chain & $\begin{array}{l}\text { Waste } \\
\text { plan }\end{array}$ & $\begin{array}{l}\text { Actual } \\
\text { waste }\end{array}$ & $\begin{array}{l}\text { Varia } \\
\text { nce }\end{array}$ \\
\hline Restaurant1 & KFC & 0.5 & 0.4 & 0.1 \\
\hline Restaurant2 & KFC & 0.7 & 0.7 & 0 \\
\hline Restaurant3 & KFC & 0.7 & 0.9 & -0.2 \\
\hline Restaurant4 & KFC & 0.7 & 1 & -0.3 \\
\hline Restaurant5 & KFC & 0.7 & 0.8 & -0.1 \\
\hline & & & & \\
\hline Restaurant1 & Hardees & 0.7 & 0.7 & 0 \\
\hline Restaurant2 & Hardees & 0.4 & 0.4 & 0 \\
\hline Restaurant3 & Hardees & 0.7 & 0.7 & 0 \\
\hline Restaurant4 & Hardees & 0.7 & 0.7 & 0 \\
\hline Restaurant5 & Hardees & 0.4 & 0.4 & 0 \\
\hline & & & & \\
\hline Restaurant1 & Burger King & 0.2 & 0.4 & -0.2 \\
\hline Restaurant2 & Burger King & 0.2 & 0.1 & 0.1 \\
\hline Restaurant3 & Burger King & 0.2 & 0.3 & -0.1 \\
\hline Restaurant4 & Burger King & 0.2 & 0.2 & 0 \\
\hline Restaurant5 & Burger King & 0.2 & 0.4 & -0.2 \\
\hline & & & & \\
\hline Restaurant1 & Prego & 0.4 & 1 & -0.6 \\
\hline Restaurant2 & Prego & 0.4 & 0.9 & -0.5 \\
\hline & & -12 & & \\
\hline
\end{tabular}




\begin{tabular}{|c|c|c|c|c|}
\hline Restaurant3 & Prego & 0.4 & 1 & -0.6 \\
\hline Restaurant4 & Prego & 0.4 & 1 & -0.6 \\
\hline Restaurant5 & Prego & 0.4 & 0.9 & -0.5 \\
\hline Restaurant1 & Arabiata & 0.7 & 1.2 & -0.5 \\
\hline Restaurant2 & Arabiata & 0.7 & 1.1 & -0.4 \\
\hline Restaurant3 & Arabiata & 0.7 & 1.2 & -0.5 \\
\hline Restaurant4 & Arabiata & 0.7 & 1 & -0.3 \\
\hline Restaurant5 & Arabiata & 0.7 & 0.8 & -0.1 \\
\hline Restaurant1 & $\begin{array}{l}\text { Batates \& } \\
\text { Zalabya }\end{array}$ & 0.5 & 0.8 & -0.3 \\
\hline Restaurant2 & $\begin{array}{ll}\text { Batates } & \& \\
\text { Zalabya } & \end{array}$ & 0.5 & 0.8 & -0.3 \\
\hline Restaurant3 & $\begin{array}{ll}\text { Batates } \quad \& \\
\text { Zalabya }\end{array}$ & 0.5 & 0.9 & -0.4 \\
\hline Restaurant4 & $\begin{array}{l}\text { Batates } \quad \& \\
\text { Zalabya }\end{array}$ & 0.5 & 1 & -0.5 \\
\hline Restaurant5 & $\begin{array}{l}\text { Batates } \quad \& \\
\text { Zalabya }\end{array}$ & 0.5 & 0.8 & -0.3 \\
\hline
\end{tabular}

\section{Reasons for waste deviations.}

This question is considered one of the most important questions because it illustrates the reasons for waste deviation from the restaurants `s point of view.

\section{A comparison between deviated restaurants and the nearest ones.}

The purpose of this question is to compare the waste percentage deviation of the restaurant with the nearest restaurants in the area. 
- Controlling Waste Makes a Difference at the Fast Food Restaurants

Table 3: The number of deviated restaurants compared to the nearest restaurants

\begin{tabular}{|l|l|l|}
\hline \multicolumn{3}{|c|}{ The number of deviated restaurants } \\
\hline Chain & $\begin{array}{l}\text { Deviated } \\
\text { Restaurants }\end{array}$ & $\begin{array}{l}\text { Compared to the } \\
\text { nearest restaurants }\end{array}$ \\
\hline KFC & 3 & Same area \\
\hline Hardees & 0 & Not located \\
\hline Burger King & 3 & Different areas \\
\hline Prego & 5 & Same area \\
\hline Arabiata & 5 & Different areas \\
\hline Batates \& Zalabya & 5 & Different areas \\
\hline
\end{tabular}

\section{- Making a waste audit.}

This question is designed to show if there is an audit to evaluate the waste.

\section{- The labor plan`s situation.}

The question indicates if the labor plan is sufficient to achieve the business goals.

\section{- The ordering system in the place.}

This question illustrates if there is an ordering system in the place.

\section{- The store room condition.}

The question indicates if the store room is always clean and tidy.

\section{- Operating spare products.}

This question illustrates if the spare products are available all times.

\section{- Shortening management.}

This question indicates if there is a shortening management system in the restaurants.

\section{Major Findings}




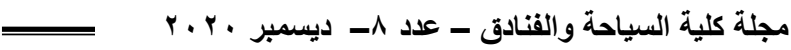

1-The waste plan differs from chain to chain, also differs from restaurant to restaurant at the same chain.

2- The customer profile is different, and also the menu items are different.

3-Deviated restaurants at waste plan are in the same area at two chains, at different areas at three chains and no deviated restaurants at one chain.

4-Half restaurants are making audits to evaluate the waste and the other restaurants do not make.

5-The most of investigated restaurants have a shortage in labor plan.

6-All investigated restaurants have an ordering system which is ordering per thousand system.

7-All investigated restaurants assured that the store room is clean and tidy all the time.

8-Only one chain do not have spare from products all time.

9-The most of investigated restaurants are using shortening management system.

\section{Conclusions and Recommendations}

Waste is a key issue for restaurants. To successfully reduce consumer-related food waste, it is necessary to have a clear understanding of the factors influencing food waste-related consumer perceptions and behaviors. Controlling waste can save a lot of money. This money can be used in the business development and also, in increasing the employees' loyalty to the business.

\section{Table 4: Some of references that agree with collected results (the resemblance points)}

The resemblance points at all restaurants

\begin{tabular}{|l|l|}
\hline The Reached Results & Relevant Research Evidence
\end{tabular}




\begin{tabular}{|c|c|}
\hline $\begin{array}{l}\text { Poor management leads to } \\
\text { increase at waste. }\end{array}$ & $\begin{array}{l}\text { Chung-Herrera et al., (2003), } \\
\text { English et al.,( 2007), Lolli, } \\
\text { (2013). }\end{array}$ \\
\hline $\begin{array}{l}\text { The shortage in labor plan } \\
\text { causes increase in waste. }\end{array}$ & $\begin{array}{l}\text { Creedon et al., (2010), Ferreira } \\
\text { et al,,(2013), Environmental } \\
\text { Protection Agency of the } \\
\text { United States, (2014), } \\
\text { Charlebois et al., (2015), } \\
\text { Tonjes, (2016). }\end{array}$ \\
\hline $\begin{array}{l}\text { The home delivery service is a } \\
\text { major cause in increasing } \\
\text { waste. }\end{array}$ & $\begin{array}{l}\text { Lindgreen et al.,( } 2000) \text {, } \\
\text { Boshoff and Gray ,(2004), } \\
\text { Gupta et al., (2007). }\end{array}$ \\
\hline $\begin{array}{l}\text { The menu flyers and menu } \\
\text { board do not explain the } \\
\text { components of each item. }\end{array}$ & Ladhari et al., (2008). \\
\hline $\begin{array}{l}\text { The layout of equipments } \\
\text { causes increase in waste. }\end{array}$ & $\begin{array}{l}\text { Rodgers, (2005), Panisello and } \\
\text { Quantick, (2001). }\end{array}$ \\
\hline \multicolumn{2}{|c|}{$\begin{array}{l}\text { Table 5: Some of references that agree with collected } \\
\text { results (the different points) }\end{array}$} \\
\hline \multicolumn{2}{|c|}{ The different points at all restaurants } \\
\hline The Reached Results & Relevant Research Evidence \\
\hline $\begin{array}{l}\text { The customer profile and the } \\
\text { nature of the menu are different. }\end{array}$ & Balazic et al., (2013). \\
\hline $\begin{array}{l}\text { The capital invested differs } \\
\text { from company to other } \\
\text { especially at local companies } \\
\text { and this affects the investment }\end{array}$ & Bond et al., (2013). \\
\hline
\end{tabular}




\begin{tabular}{|c|c|}
\hline $\begin{array}{l}\text { in equipments and delivery } \\
\text { vehicles. }\end{array}$ & \\
\hline $\begin{array}{l}\text { The multinational restaurants } \\
\text { have the advantage to attract } \\
\text { staff quality higher than local } \\
\text { restaurants as per brand equity. }\end{array}$ & Groonroos, (2000). \\
\hline $\begin{array}{l}\text { Not all of the restaurants are } \\
\text { keeping spare items all time. }\end{array}$ & $\begin{array}{l}\text { United States Environmental } \\
\text { Protection Agency, (2014). }\end{array}$ \\
\hline
\end{tabular}

\section{On the literature review and the results obtained during the study, the following recommendations could be suggested:}

1-The waste plan should be smart and as per the actual waste achieved last year at the same store and may differ from a restaurant to another.

2- The restaurants should work by the golden rule (treat people as you want to be treated) to reduce staff turnover.

3- Changing or fixing any broken (cooler, freezer, fryer, holding cabinet, display cabinet and any equipment) may decrease waste at these sample of restaurants.

4- Saving the appropriate number of delivery vehicles may help in applying accurate food cycle.

5- Offering superior home delivery service should decrease waste.

6- The menu board and menu flyers should explain the components of each item completely.

7- It is advised to Coordinate with the upper management for not saving all products at all-times especially at low volume restaurants.

8- The mangers should be selected very carefully and should be developed continuously.

\section{References}


- Alfagi,A. Purnaweni,H. and Setiani,O. (2015). Waste management in KFC and Pizza Hut case study in Semarang,Indonesia.volume2015.article ID sjeer.285,15 pages2015.doi:10.7237/sjeer/285.

- Beatson, A. Lings, I. and Gudergan, S. (2008). Employee behavior and relationship quality: Impact on customers. The Service Industries journal, 28(2), PP. 211-223.

- Charlebois,S. and Massow,M.(2015)."Back of house" focused study on food waste in fine dining : The case study of Delish restaurants,9 (3), PP.278-291.

- Darqui,B.Foyer,T. and Fernandez,V.( (2016).Towards a more sustainable food supply chain: Opening up invisible waste in food service,8 (7),PP.693.

- El Alami,J. and Hlyal,M.(2017).Inventory management of supply chain with robust control theory: literature review,27(4),PP.438-465.

- Ghauri,p. and Gronhaug,K.(2005).Research Methods in Business Studies- A Practical Guide. THIRD EDITION, Prentice Hall.

- Göbel,C.Langen,N.Blumenthal,N. Teitscheid,P. and Ritter,G. (2015). Cutting food waste through cooperation along the food supply chain, 7 (2), PP.1429-1445.

- Hisam,M. Sanyal,S. and Ahmad,M.( (2016). The impact of service quality on customer satisfaction: A study on selected retail stores in India, 6(4), PP.851-856.

- Hui,Y.Bruinsma,B.Gorham,J.Nip,W.Tong,P.andVentresca,P. (2003).Food plant sanitation, New York. Basel, Marcel Dekker, Inc. 
مجلة كلية السياحة والفنادق - عدد A- ديسمبر .r.r

- Ivkov,M.Blešić,I.Stefanović,V. and Raljić,J. (2014). Managing customer satisfaction in the restaurant industry: A world from managers, 52(3), PP.369-378.

- Josiam,B.Malve,R. and Baldwin,W. (2014).Assessing quality of food, service and customer experience at a restaurant: The case of a student run restaurant in the USA, 14(1) AprilSeptember 2014,PP.1-26.

- Lefadola,B. Viljoen,A. and Du Rand,G. (2018).A system approach to food waste prevention in food service operation: An integrative review, 7(4), PP. 1-15.

- Mabaso,C and Hewson,D.(2018). Employees' perceptions of food waste management in hotels,7(4).PP.1-16.

- Marriot,N.Schilling,W. and Gravani,R.(2018). Principals of Food Sanitation. SIXTH EDITION, Switzerland, Springer.

- Montgomery,D.(2009).Introduction to Statistical Quality Control.SIXTH EDITION,USA, John Wiley \& Sons, Inc.

- Ngozika,E. and Ifeanyi,O.(2018). A review on fast foods and family lifestyle, 3(4), PP.26-30.

- Raab,C.Mayer,K. and Shoemaker,S. (2010).Menu engineering using activity-based costing: An exploratory study using a profit factor comparison approach,34(2),PP.

204-224.

- Rios,C.Meier,C,Gössling,S. and Cornuz,C.(2018). Food waste management innovations in the food service industry, 79 September2018, PP. 196-206.

- Saunders, M. Lewis, P. and Thornhill, A. (2007). Research Methods for Business Students. FOURTH EDITION. Essex, UK, Pearson Professional Ltd. 
- Shahzad,N.(2018). Impact of employee motivation on customer satisfaction: Study of airline industry in Pakistan, 3(2), PP.1-5.

- Sibanyoni, J. Tabit,F and Annan, C. (2018). An exploration of the internal communication practices in hotels of Gauteng province, South Africa, 7(4), PP.1-21.

- Susskind, A. Kacmar, K. and Borchgrevink, C. (2003). Customer service providers' attitudes relating to customer service and customer satisfaction in the customer-server exchange. Journal of applied psychology, 88(1), PP.179-187.

- Wen,T.Li,H.Ping,L.Shiue,L. and Hui,W.(2013). The relationships among employee personality traits, service attitude, and service behavior in the leisure farm, 1(2), PP.75-88.

- Wang, Y. Wang,L. Xue,H. and Qu,W.(2016). A review of the growth of the fast food industry in China and its potential impact on obesity, 13(1112), PP.1-16. 